\title{
The Effectiveness of the Strategy for Empowering Micro, Small and Medium Enterprises (MSMES) During the 2020 Covid-19 Pandemic at the NTB Province Cooperatives and SMES Office
}

\author{
Lia Fitriani ${ }^{1}$, Muhammad Ali ${ }^{2}$, Lalu Hendra Maniza ${ }^{3}$ \\ ${ }^{123}$ Universitas Muhammadiyah Mataram \\ ${ }^{1}$ liafitriani0199@gmail.com ${ }^{2}$ Khaidiraliihsan@gmail.com ${ }^{3}$ Manizahendra@gmail.com
}

\begin{abstract}
One of the attempts to recover micro-enterprises from the effects of the Covid 19 outbreak is the empowerment of micro, small and medium-sized enterprises by the SME Cooperative Office of West Nusa Tenggara Province. The empowerment given is in the form of a program involving Micro and Small Enterprises to provide a Social Security Net (SSP) and provide economic stimuli to encourage resources. This assistance is used to restore the economy of the citizens affected by the Covid-19 Pandemic by providing the opportunity to generate their business results as a means of involvement in preventing Covid-19, which would help the Micro and Small $\mathrm{Bu}$ affected. Also, it can provide an opportunity to start a business Back during the economic crisis. Some problems occur in its implementation, namely the lack of capital to empower all Micro and Small Businesses Affected by the Covid-19 Pandemic so that not all Micro and Small Businesses in West Nusa Tenggara Province can be empowered. This study aimed to describe and analyze the strategy's effectiveness for the empowerment of Micro, Small, and Medium Enterprises (MSMEs) during the Covid-19 Pandemic in 2020 at the West Nusa Tenggara Province UKM Cooperative Office. The research method used is a descriptive qualitative approach. The informants used in this study used the purposive sampling technique. The research informants consisted of the head of the UKM Division, the Head of the UKM Development Section, the Head of the NTB Province UKM Koprasi Program Division Head, and Empowered UKM Players. Data collection techniques used interviews, observation, and documentation. Data analysis was performed by collecting data, data reduction, data presentation, and conclusions. The results of this study showed that the effectiveness of the Strategy for the Empowerment of Micro, Small, and Medium Enterprises during the 2020 Covid-19 Pandemic in the West Nusa Tenggara Province of the UKM Cooperative Service could not be said to be good because only two indicators have been defined as good. They are indicators of targeting accuracy and the social program.
\end{abstract}

Keywords: Effectiveness, Strategy, Empowerment 


\title{
Efektivitas Strategi Pemberdayaan Usaha Mikro Kecil Dan Menengah (UMKM) Dimasa Pandemi Covid-19 Tahun 2020 Pada Dinas Koperasi Dan UKM Povinsi NTB
}

\begin{abstract}
ABSTRAK
Salah satu upaya pemulihan usaha bagi usaha ultra mikro terhadap dampak wabah Covid 19 yaitu dengan pemberdayaan usaha mikro kecil dan menengah yang dilakukan oleh Dinas Koperasi UKM Provinsi Nusa Tenggara Barat. Pemberdayaan yang diberikan berupa pentukan program yang melibatkan para usaha Mikro Kecil dalam penyediaan jaring Pengaman Sosial (JPS) dan pemberian Stimulus ekonomi dalam bentuk fasilitasi pemberian modal. Bantuan ini digunakan untuk memulihkan ekonomi masyarakat yang terdampak Pandemi Covid-19 dengan memberi kesempatan dalam memproduksi hasil usahanya sebagai bentuk partisipan dalam penjegahan Covid-19 yang dapat memberi keuntungan kepada Usaha Mikro Kecil yang terdampak. Serta dapat memberikan kesempatan untuk merintis usaha Kembali dimasa krisis ekonomi. Dalam pelaksanaanya terdapat permasalahan yang terjadi yaitu kurangnya modal untuk memberdayakan semua Usaha Mikro Kecil yang terdampak Pandemi Covid-19 sehingga tidak semua Usaha Mikro Kecil di Provinsi Nusa Tenggara Barat dapat diberdayakan.Penelitian ini bertujuan mendeskripsikan dan menganalisis efektivitas Strategi pemberdayaan Usaha Mikro Kecil dan Menengah (UMKM) dimasa Pandemi Covid-19 tahun 2020 pada Dinas Koperasi UKM Provinsi Nusa Tenggara Barat. Metode penelitian yang digunakan adalah deskriptif dengan pendekatan kualitatif. Informan yang digunakan dalam penelitian ini menggunakan tekhnik Purposive Sampling. Adapun informan penelitan ini terdeiri dari kepala Bidang UKM, Kepala Seksi Pengembangan UKM, Kepala Bidang Program Dinas Koprasi UKM Provinsi NTB dan Pelaku UKM yang di Berdayakan. Tekhnik pengumpulan data yang digunakan wawancara, Observasi dan Documentasi. Analisis data dilakukan dengan mengumpulkan data, reduksi data, penyajian data, dan kesimpulan.Hasil penelitian ini menunjukan bahwa untuk keefektivitasan Strategi Pemberdayaan Usaha Mikro Kecil Menengah dimasa Pandemic Covid-19 tahun 2020 pada Dinas Koperasi UKM Provinsi Nusa Tenggara Barat belum dapat dikatakan baik dari ketiga indikator yang dijelaskan hanya dua indikator yang bisa dikatakan baik, yaitu pada indikator ketepatan sasaran dan sosialisasi program.
\end{abstract}

Kata Kunci : Efektivitas, Strategi , Pemberdayaa 


\section{PENDAHULUAN}

Pandemi Covid-19 merupakan Pristiwa peneyebaran penyakit berbentuk virus diseluruh dunia. Yang disebabkan oleh Korona Virus jenis baru yang diberi nama SARSCoV-2.Wabah ini pertama kali di deteteksi dikota Wuhan tiongkok pada tahun 2019, dan ditetapkan sebagai pandemi oleh Organisasi Kesehatan dunia (WHO),Virus ini terus menyebar di seluruh dunia dengan hamper 35 juta kasus terkonfirmasi 188 Negara dan lebih dari 1 juta kasus kematian (Ratclife,Rebecca,2010) Pemerintah sendiri telah Menyusun dampak dari Covid-19 terhadap Ekonomi serta penurunan penghasilan masyraakat pada setiap Provinsi berdasarkan scenario ringan,sedang, hingga buruk, scenario mengacu pada dayatahan ekonomi setiap provinsi maupun penurunan pendapatan pada pelaku ekonomi, dalam skenario sedang pengaruh ekonomi berdampak $25 \%$ pendapatan buruh menurun di Nusa Tenggara Barat (Selanjutnya NTB) an mampu bertahan pada akhir 2020.

Pandemi Covid-19 semakin mengancam perekonomian Indonesia (termasuk Provinsi NTB), dan dampaknya terlihat jelas dari wabah yang meletus pada awal Februari 2020. Toko, ritel, jasa perjalanan, usaha mikro, kecil dan menengah (selanjutnya disebut UMKM) dan Industri Kecil Menengah (IKM) NTB tutup. Hal ini mengakibatkan sejumlah besar relawan dan karyawan dipulangkan. Oleh karena itu, Pemprov telah bekerja keras memobilisasi usaha kecil dan menengah untuk memperlambat perlambatan ekonomi. Sementara itu, menurut data penulis Dinas Perindustrian NTB, sebanyak 5.000 UMKM dan IKM terdampak akibat wabah Covid-19 di NTB. Data tersebut masih menjalani verifikasi bersama dengan Dinas Sosial NTB, Dinas Pemberdayaan Masyarakat NTB, Dinas Kependudukan dan Pendaftaran Warga, dan pemerintah desa. Pandemi Covi-19 berdampak signifikan pada sektor UMKM / IKM, mulai dari penurunan omzet, arus kas yang terputus, dan kredit macet, hingga peningkatan PHK pekerja. Dibandingkan dengan biasanya, beberapa pedagang yang merasakan dampak korona adalah pedagang di pinggir jalan. Salah satunya pelapak di Kota Mataram, Provinsi NTB yang penghasilannya jauh dibandingkan gempa Lombok sebelum 2018. Badan Pusat Statistik (BPS) Indonesia menunjukkan dampak Covid-19 cukup dalam hingga mencapai negatif 5,32. \% jauh dari krisis terakhir tahun 1998 dan 2008. Data terakhir menunjukkan bahwa $98 \%$ usaha di sektor mikro atau sekitar 68 juta orang terkena dampaknya. Dampak 
pandemi Covid-19 adalah akibat perlambatan ekonomi. dan Pembatasan sosial telah menyebabkan penurunan permintaan publik.

UMKM merupakan salah satu bagian terpenting dalam perekonomian dan pembangunan nasional. Mengingat sektor UMKM merupakan motor penggerak perekonomian dan pembangunan nasional, maka diperlukan suatu strategi peningkatan kapasitas sektor UMKM. Hal ini bertujuan untuk mendukung upaya penanggulangan kemiskinan dan ketimpangan serta peningkatan kesempatan kerja. Selama pandemi Covid19, Kementerian Koperasi dan Usaha Kecil dan Menengah telah merumuskan berbagai strategi untuk mendorong UMKM dan koperasi menjaga kapasitasnya. Bertahan dan bangkit dalam pandemi Covid-19. Di mana Kementerian pertama kali menerapkan berbagai kebijakan, Kementerian Koperasi dan Usaha Kecil dan Menengah melakukan reorganisasi untuk memberikan kredit kepada peserta UMKM, sehingga membantu koperasi dan UMKM untuk bertahan dan bangkit dalam pandemi Covid-19, dengan tujuan untuk memberikan kredibilitas kepada mereka. Ditunda hingga 6 bulan ke depan, kedua, akan dibuka sistem permodalan ringan baru bagi peserta UMKM dan koperasi.

Berbagai masalah yang dihadapi UMKM di Indonesia sebagai akibat dari pandemi Covid-19 memerlukan perhatian khusus. Sekitar 98,68\% dari 64 juta UMKM di Indonesia merupakan jenis Usaha Mikro yang dikerjakan secara mandiri dan rentan terhadap gangguan Internal dan Esternal. Meskipun UMKM memiliki peran penting, akan tetapi belum diketahui sejauh mana Covid-19 berdampak kepada kelompok usaha ini. Pemerintah Provinsi Nusa Tenggara Baratsendiri menyiapkan berbagai program pemenuhan danpemulihan kebutuhan sosial ekonomi telah diluncurkan oleh Gubernur Nusa Tenggara Barat yang sejalan dengan nafas industrialisasi sebagai program unggulan Nusa Tenggara Barat Gemilang, Dimana salah satunya melalui program Jaring Pengaman Sosial(JPS) Gemilang yang bertujuan untuk bisa memenuhi kebutuan masyarakat miskin se-NTB selama 3 bulan kedepan. JPS Gemilang ini menyiapkan 105.000 paket yang berisi; Senbako, Produk Perikanan,Obat, Vitamin dan alatpelindung diri (Masker) Yang semuanya diambil dari prooduk Lokal hasil dari UMKM. Dengan adanya langah ini dapat memberdayakan UMKM yang terdampak Pandemi Virus Covid-19. 
Pemerintah Daerah diNTB terus memberdayakan dan memperkuat peran UKM serta pengusaha lokal. Baik untuk meproduksi Masker, APD hingga kebutuhan pangan lainnya, Hal tersebut untuk terus memberdayakan UKMKM/IKM di NTB sehingga Roda perekonomian dapat teru berputar, selain itu pemerintah NTB juga memperlakukan Badan Usaha Milik Desa (BUMDES)"yang ada di masing-masing Desa disetiap kabupaten dimulai dari Desa Kuripan Utara Kabupaten Lombok Barat, pemerintah Provinsi NTB meresmikan Tradedan Distribution Centre (selanjutnya TDC) yang menjadi milik BUMDES, dengan adanya TDC bertujuan untuk mrnyalurkan hasil produk-produk UMKM masyarakat NTB yang dbutuhkan waga dan Warung-warung kecil sekaian menjadi Autlet dan penyalur Produk UMKM di NTB..

Upaya tersebut merupakan bagian dari strategi pemerintah untuk meningkatkan perekonomian dan kesejahteraan masyarakat NTB. Selama pandemi Covid-19, strategi ini digunakan untuk menciptakan dan mengembangkan sumber daya guna mencapai kemakmuran. Oleh karena itu, penerapan strategi ini diharapkan dapat menentukan efektif atau tidaknya hasil yang ingin dicapai. Adapun yang dimkasud disini ialah Strategi Pemberdayaan yang memfokuskan pada Perencanaan Strategi UMKM yang leih berorientase pada pemberdayaan secara Makro. Melihat Kondisi keterpurukan ekonomi dimasa Pandemi Covid-19 tentunya peran Stakeholder dalam mengimplementasikan Strategi Pemberdayaaan tersebut sangat diharapakan. Dengan demikian Dinas Koperasi UKM Provinsi NTB mengeluarkan beberapa kebijakannya dalam memberdayakan UMKM pada masa Pandemi Covid-19 tahun 2020 diantaranya menerapkan kebijakan seperti ; Membentuk Program Pengadaan Barang dan Jasa untuk Jaring Pengaman Sosial (JPS) Gemilang dan Membentuk Stimulus ekonomi dalam bentuk Fasilitasi pemberian Modal bagi Koperasi dan UKM. 
TABEL 1.2

USAHA MIKRO KECIL DAN MENENGAH

(UMKM) YANG TERDAMPAK COVID-19 PROVINSI

NUSA TENGGRA BARAT TAHUN 2020

\begin{tabular}{|c|c|c|c|c|c|}
\hline \multirow{2}{*}{$\begin{array}{l}\mathbf{N} \\
\mathbf{0}\end{array}$} & \multirow{2}{*}{$\begin{array}{c}\text { Kab/Kot } \\
\mathbf{a}\end{array}$} & \multicolumn{3}{|c|}{ Klasifikasi Usaha } & \multirow[t]{2}{*}{ Jumlah } \\
\hline & & Mikro & Kecil & $\begin{array}{c}\text { Menenga } \\
\mathbf{h}\end{array}$ & \\
\hline 1 & $\begin{array}{l}\text { Kota } \\
\text { Mataram }\end{array}$ & $\begin{array}{c}15.746 .74 \\
6\end{array}$ & $\begin{array}{c}66.194 \\
4\end{array}$ & 5333 & $\begin{array}{c}22.4732 .47 \\
3\end{array}$ \\
\hline 2 & $\begin{array}{l}\text { Lombok } \\
\text { Barat }\end{array}$ & 3.612 & 366 & 0 & 3.978 \\
\hline 3 & $\begin{array}{l}\text { Lombok } \\
\text { Utara }\end{array}$ & 145 & 71 & 95 & 311 \\
\hline 4 & $\begin{array}{l}\text { Lombok } \\
\text { Tengah }\end{array}$ & 309 & 11 & 3 & 323 \\
\hline 5 & $\begin{array}{l}\text { Lombok } \\
\text { Timur }\end{array}$ & 4.261 & 34 & 2 & 4.297 \\
\hline 6 & $\begin{array}{l}\text { Sumbaw } \\
\text { a Barat }\end{array}$ & 5.716 & 303 & 23 & 6.042 \\
\hline 7 & $\begin{array}{l}\text { Sumbaw } \\
\text { a }\end{array}$ & 959 & 46 & 4 & 1.009 \\
\hline 8 & Dompu & 1.323 & 112 & 1 & 1.436 \\
\hline 9 & $\begin{array}{l}\text { Kab } \\
\text { Bima }\end{array}$ & 307 & 7 & 3 & 317 \\
\hline 1 & $\begin{array}{l}\text { Kota } \\
\text { Bima }\end{array}$ & 6.621 & 1.152 & 132 & 7.905 \\
\hline & Jumlah & 38.999 & 8.296 & 796 & 48.091 \\
\hline
\end{tabular}

Sumber : Dinas Koperasi UKM Provinsi NTB 
Dari data tersebut menunjukkan pesebaran dampak Pandemi Covid-19 terhadap sector UMKM yang ada di seluruh kabupaten /kota Provinsi NTB dimana klasifikasi Usaha dapat dilihat mulai dari dampak pada Sektor Mikro berjumlah 38.999 usaha, usaha Kecil berjumlah 8.296 usaha dan Sektor Menengah berjumlah 796 usaha yang terkena dampak dengan adanya Pandemi Covid-19 ini sehingga total dari keseluruhan UMKM yang terdampak berjumlah 48.091 unit usaha.

\section{TINJAUAN PUSTAKA}

Definisi”Usaha Kecil” Menengah (UKM)" di Indonesia sendiri memiliki beberapa versi. menurut Undang-Undang”Nomer 20 Tahun 2008,” Klasifikasi UKM Didasarkan atas kekayaan dan hasil penjualan selama satu tahun. "Kriteria Usaha kecil sebagai berikut :"

a. Sebuah usaha kecil memiliki kekayaan bersih melebihi Rp. 50.000.000,00 (50 juta rupiah), perusahaan dengan nilai tertinggi Rp. 500.000.000,00 (lima miliar rupiah), tidak termasuk tanah dan bangunan komersial;

b. Penjualan tahunan melebihi 300 juta rupiah (300 juta rupiah), hingga 2,5 miliar rupiah (2 miliar dan 5 juta rupiah).

c. Aktiva bersih perusahaan menengah melebihi $500.000 .000,00$ rupee India (500 juta rupiah), dan maksimum 10.000.000.000,00 rupee India (crores), tidak termasuk tanah dan bangunan tempat usaha;

d. Penjualan tahunan melebihi 2.5 milyar rupiah (2.5 milyar rupiah), dan tertinggi bisa mencapai 50 milyar rupiah (50 milyar rupiah).

DiIndonesia UKM, memililiki peran yang sangat penting msyarakat menyadari daya tahan UKM terhadap krisis ekonomi tahun 1998 misalnya. Hal ini terjadi kerena sifat UKM yang sangat fleksibel dibandingkan dengan perusahaan besar. (Berry Tambunan :2009) menyebut UKM mampu menghadapi turbolensi ekonomi makro maupun perubahan kondisi 
ekonomi dengan baik. Lebih jauh,studi yang dilakukan (Urata:2000) Menjelaskan peranperan penting UKM di Indonesia. Beberapa perannya yaitu :

1. Penyedia kesempatan kerja

2. Berperan penting dalam pembangunan ekonomi lokal dan pengembangan masyarakat

3. Menciptakan dan berinovasi pasar melalui fleksibilitas dan kepekaan dan hubungan dinamis antara aktivitas perusahaan.

4. Meningkatkan ekspor nonmigas.

Permasalahan yang dihadapi oleh UKM antara lain meliputi:

a) Faktor Internal:

1. Kekurangan dana merupakan faktor utama yang dibutuhkan untuk mengembangkan dunia usaha.

2. Sumber daya manusia terbatas.

3. Jaringan bisnis yang lemah dan kemampuan penetrasi bisnis kecil.

b) Faktor Eksternal:

1. Lingkungan usaha belum sepenuhnya kondusif bagi kebijakan pemerintah dalam mengembangkan UKM.

2. Fasilitas dan infrastruktur komersial terbatas.

3. Akses pasar terbatas. Akses pasar akan menyebabkan produk akhir tidak dapat dijual secara kompetitif di pasar domestik dan internasional.

4. Akses informasi dibatasi.

Dengan melihat permasalahan yang dihadapi UMKM dan langkah-langkah yang telah dilakukan selama ini, maka langkah-langkah yang harus diambil adalah:

1. Ciptakan Suasana Bisnis Yang Menyenangkan.

2. Bantuan Keuangan

3. Perlindungan Komersial. .

4. Pengembangan Kemitraan.

5. Pelatihan. .

6. Mendirikan Badan Khusus 


\section{Pembangunan Sarana Dan Prasarana}

Menurut David (2011:18-19) Strategi adalah sarana bersama dengan tujuan jangka panjang yang hendak dicapai. Strategi bisnis mencakup ekspansi georafis, diversifikasi, akusisi, pengembangan produk, penetrasi pasar, pengetatan, divestasi, likuidasi, dan usaha patungan atau joint venture. Strategi adalah aksi potensial yang membutuhkan keputusan manajemen puncak dan sumber daya perusahaan dalam jumlah besar. Jadi strategi adalah sebuah tindakan aksi atau kegiatan yang dilakukan oleh seseorang atau perusahaan untuk mencapai sasaran atau tujuan yang telah di tetapkan.

Rencana strategis adalah proses menganalisis, merumuskan, dan mengevaluasi strategi yang digunakan manajer untuk mengatasi ancaman eksternal dan memanfaatkan peluang yang ada. Tujuan utama dari renstra adalah agar organisasi dapat secara obyektif melihat kondisi internal dan eksternal sehingga organisasi dapat mengantisipasi perubahan lingkungan eksternal. Rencana strategis (Renstra) merupakan dokumen perencanaan yang berorientasi pada hasil, yang harus diselesaikan dalam waktu 1 sampai 5 tahun terkait dengan tanggung jawab dan fungsi perangkat daerah, dan pengembangan lingkungan strategis harus dipertimbangkan dan lebih baik.

Bryson (2007:12.13), perencanaan strategis memiliki beberapa manfaat, yaitu : Berfikir secara strategis dan mengembangkan strategi-strategi yang efektif.

a. Memperjelas arah masa depan.

b. Menciptakan prioritas

c. Membuat keputusan sekarang dengan mengingat konsekuensi masa depan.

d. Mengembangkan landasan yang koheren dan kokoh bagi pembuat keputusan.

e. Menggunakan kekuasaan yang maksimum dalam bidang-bidang yang berada di bawah kontrol organisasi.

f. Membuat keputusan yang melintasi tingkat dan fungsi.

g. Memecahkan masalah utama organisasi.

h. Memperbaiki kinerja organisasi.

i. Menangani keadaan yang berubah dengan cepat secara efektif.

j. Membangun kerja kelompok dan keahlian. 


\section{Prinsip-Prinsip Pemberdayaan Masyarakat}

1. Prinsip Kesetaraan

Prinsip utama yang harus dipegang teguh dalam proses pemberdayaan masyarakat adalah adanya kesetaraan atau kesamaan status antara masyarakat dengan lembaga yang melaksanakan rencana pemberdayaan masyarakat (tanpa memandang gender).

2. Prinsip Partisipasi

Rencana pemberdayaan yang dapat menginspirasi kemandirian masyarakat adalah rencana yang melibatkan partisipasi masyarakat, perencanaan, pelaksanaan, pemantauan, dan evaluasi.

3. Keswadayaan atau kemandirian

Prinsip keswadayaan adalah menghargai dan mengedepankan kemampuan masyarakat daripada bantuan pihak lain. Konsep ini tidak memandang orang miskin sebagai obyek yang tidak berkemampuan (the have not), melainkan sebagai subjek yang memiliki kemampuan sedikit (the have little).

4. Berkenlanjutan

Program pemberdayaan perlu dirancang untuk berkelanjutan, sekalipun pada awalnya peran pendamping lebih dominan dibanding masyarakat sendiri.

\section{METODE PENELITIAN}

Jenis penelitian kualitatif dan deskriptif digunakan dalam penelitian ini. Penelitian kualitatif adalah penelitian deskriptif dan cenderung menggunakan analisis. Kemudian, metode penelitian deskriptif adalah metode yang meneliti keadaan terkini dari sekelompok orang, suatu objek, sekumpulan kondisi, sekumpulan sistem pemikiran, atau serangkaian peristiwa. Tujuan dari studi deskriptif ini adalah untuk secara akurat mendeskripsikan, mendeskripsikan atau melukiskan fakta, karakteristik dan sistem relasional dari fenomena yang diteliti (Nazir (1988: 63)). 


\section{HASI DAN PEMBAHASAN}

Dinas Kopersi Usaha Kecil dan Menengah Provinsi Nusa Tenggara Barat merupakan salah satu organisasi perangkat Daerah (ODP) yang mempunyai tugasmembantu Gubernur dalam melaksanakan urusan pemerintahan dalam urusan bidang Koperasi dan Usaha Mikro Kecil dan Menengah berdasarkan asas otonomi tugas pembantuan dan dekonsentrasi dinas Koperasi UKM Provinsi NTB oleh Drs.Wirajaya Kusuma MH, Sebagai Kepala Dinas dan dibawa oleh 1 orang sekretaris, 4 orang kepada Bidang dan 1 orang kepala Balai Diklat Koperasi UKM sebagai Unit Pelaksana tekhnik Daerah (UPTD).

Dalam melaksanakan tugas pokok sebagaimana dimaksud dalam Pasal 27 ayat (1) tahun 2008, fungsi Dinas Koperasi Usaha Kecil dan Menengah Provinsi Nusa Tenggara Barat adalah sebagai berikut:

1. Perumusan kebijakan tenis pada Bidang Koperasi Usaha mikro Kecil dan Menengah.

2. Pembinaan dan pelaksanaan tugas urusan pemerintahan bidang Usaha Kecil dan Menengah bidang Koperasi.

3. Pembinaan dan pelaksanaan tugas urusan pemerintahan bidang Usaha Kecil dan Menengah.

4. Pelaksanaan tugas lain yang diberikan Gubernur sesuai dengan tugas dan fungsi Dinas Koperasi Usaha kecil dan Menengah.

Keberadaan Dinas Koperasi UKM provinsi NTB seagai organisasi perangkat daerah diharapkan mampu mengakomodir permasalahan yang dihadapi oleh koperasi dan UMKM, memperkuat pondasi perekonomian daerah dan nasional melalui pemberdayaan Koperasi Usaha Kecil dan Menengah (KUKM) 
Pandemik Covid-19 berdampak besar bagi banyak sektor. Kebijakan pemerintah terkait pandemic telah menghambatt aktivitas sehari-hari hingga aktivitas jual beli yang dilakukan oleh UMKM. Peran UMKM sangatlah penting melihat krisis ekonomi yang akan datang diakibatkan Pandemi ini, Hasil survey menunjukkan bahwa kegiatan bisnis para pelaku UMKM benar-benar terdampak oleh Pandemi Covid-19 yang sedang terjadi sekarang ini. Hal ini ditunjukkan dengan adanya penuruna nomset, penurunan order, dan penurunan pendapatan serta kendala-kendalaa lain terkait ddengan kegiatan usaha seperti proses produksi, pemasaran, dan distribusi. para pelaku UMKM mengharapkan adanya bantuan dana/modalf usaha, pemasaran produk,dan kebutuhan pokok.

Untuk mmemastikan pemberdayaan UKM dan IKM pemerintah Provinsi Nusa Tenggara Barat. Menyusun peraturan Gubernur (Pergub) untuk melindungi dunia usaha dan produk Lokal di NTB. Kebijakan pemerintah tentang bantuan untuk masyarakat terdampak wabah dimasa pandemic pemenuhan dan pemulihan kebutuhan sosial ekonomi telah diluncurkan oleh Gubernur NTB yang sejalan dengan nafas industrialisasi sebagai program unggulan NTB Gemilang. Berbagai rencana telah disiapkan bersama IKM / UMKM dan pengusaha lokal sebagai target pemberdayaan untuk mencapai pemulihan ekonomi akibat pandemi Covid-19. Prosedur ini termasuk :

1. Jaring Pengaman Sosial JPS Gemilang.

Untuk membantu 105.000 keluarga kurang mampu dan keluarga di sektor formal / informal yang terdampak Covid-19, bantuan selama tiga bulan diberikan selama keadaan darurat Covid-19. Masker dibeli langsung dari IKM / UMKM setempat.

2. memberdayaan BUMDES yang ada di desa-desa.

Pemerintah Provinsi NTB berawal dari Desa Kuripan Utara di Kabupaten Lombok Barat dan mendirikan Trade and Distribution Center (TDC) milik BUMDES. Semua produk yang dibutuhkan warga dan toko kecil bisa dimulai dari TDC. TDC juga merupakan penjual dan distributor produk UKM di NTB. Beberapa waktu lalu, NTB juga berhasil membuat booth desinfektan sendiri melalui Kawasan Industri Sains dan Teknologi (STIPARK) dan disebarkan ke masyarakat.

Dengan mengusung tema Aksi Bela dan Beli Produk Lokal NTB (Pergub 
no.43 tahun 2020), dengan harus digunakan oleh Instansi Pemerintah, Perhotelan atau retail Moedrn di daerah NTB (Manggaukang Raba, 2020:70)

Pandemi Covid-19 di Nusa Tenggara Barat mulai masuk pada tahun 2019, bencana non alam tersebut membuat perekonomian di Nusa Tenggara Barat mengalami penurunan, hal itu membuat pemerintah harus mengambil langkah dengan membuat kebijakan agar perekonomian masayarakat dapat bertahan di masa Pandemi Covid-19 tersebut. Terkait dengan kebijakan pemerintah dalam membantu perekonmian masyarakat, pemerintah melalui “Dinas Koperasi UKM Provinsi Nusa Tenggara Barat” merumuskan strategi Pemberdayaan UMKM pada masa Pandemi Covid-19,"'beberapa strategi yang dilaksanakan oleh Dinas Koperasi UKM provinsi NTB berkaitan dengan pemberdayaan Usaha Mikro Kecil diantaranya Membentuk Program yang melibatkan Koperasi dan UKM dalam penyediaan untuk Jaring Pengaman Sosial (JPS) serta Memberikan Stimulus ekonomi dalam bentuk Fasilitasi pemberian Modal,'Pengadaan Boot Portoble untuk Usaha Mikro sebanayak 105 unit,” Pengadaan Kompos Bag dan Pemberian Sertfikikasi Lebel Halal bagi UMKM. Dengan adanya progam tersebut diharapkan perekonomian masyarakat tidak mengalami penurunan, dan dapat bertahan di masa Pandemi Covid-19.

Dari hasil penelitian penulis, pada tahap 1 jumlah sasaran program JPS Gemilang menyasar pada 105.000 keluarga, dan pada tahap ke II sasarannya bertambah menjadi 125.000 keluarga pada 10 kab/kota di Nusa Tenggara Barat. Dinas Koperasi UKM Provinsi NTB dalam menjalankan Program JPS Gemilang Tahap II, telah menerapkan kebijakan bahwa semua jenis barang yang diberikan kepada masyarakat adalah berasal dari Produk Lokal masyarakat NTB, artinya bantuan tersebut adalah hasil karya UKM/IKM yang dibina Organisasi perangkat daerah (OPD) Provinsi Nusa Tenggara Barat yang ada di 10 Kabupaten /Kota . Sekitar 135 UKM/IKM yang ada di Nusa Tenggara Barat telah terlibat dalam pengadaan Maskerisasi untuk program bantuan JPS Gemilang Tahap I dan II Kondisi ini tentunya dapat mengangkat perekonomiann Sebagian Usaha Mikro di Nusa Tenggara Barat ditengah-tengah Pandemi Covid-19.

Dari hasil wawancara. peneliti menemukan tentang rencana strategi yang dilakukan oleh Dinas UKM dan Koperasi Provinsi Nusa Tenggara Barat, data tersebut menunjukan bahwa ada dua hal yang direncanankan oleh Dinas Koperasi UKM Provinsi NTB. Keduanya 
ialah melibatkan UKM dalam program JPS Gemilang dan memberikan UKM Bantuan stimulus ekonomi.

Efektivitas Strategi Pemberdayaan UMKM dimasa Pandemi Covid-19 Dinas UKM Provinsi NTB, memberikan perhatian juga kepada pelaku UKM, hal ini dilakukan karena pelaku UKM merupakan salah satu pilar penopang ekonomi masyarakat. Maka untuk membuat mereka terus memproduksi dan supaya tidak mengalami ke merosotan pendapatan dimasa Pandemi Covid-19 ini, butuh suatu strategi yang dapat memberdayakan UKM tersebut. Ini sangat perlu dilakukan mengingat masa Pandemi Covid-19 membuat banyak UKM yang mengalami kesulitan terhadap keuangan. Baik itu di sebabkan oleh daya minat beli masyarakat berkurang, atau bahkan karena akibat pengeluaran lebih besar daripada pendapatan yang diakibatkan oleh daya beli yang menurun.

Menyadari akan hal itu, pemerintah provinsi Nusa Tenggara Barat mengeluarkan strategi yang efektif untuk memberikan bantuan kepada pelaku UKM, strategi yang dilakukan itu ialah dengan di berikannya Dana Stimulus bagi para pelaku UKM yang tercatat di Dinas Koperasi UKM provinsi Nusa Tenggara Barat. Berikut ini data penerima manfaat dana Stimulus dari Dinas Koperasi UKM Provinsi Nusa Tenggara Barat .

Penerima Bantuan Stimulus Ekonomi Untuk

Bantuan Modal Usaha Bagi Pelaku Usaha

Ultra Mikro Dampak Covid 19 Provinsi Nusa

Tenggara Barat

\begin{tabular}{|l|l|c|}
\hline No & \multicolumn{1}{|c|}{$\begin{array}{c}\text { Daerah Penerima } \\
\text { Bantuan }\end{array}$} & $\begin{array}{c}\text { Jumlah } \\
\text { UKM }\end{array}$ \\
\hline 1 & Kab.Lombok Timur & 25 \\
\hline 2 & Kab. Lombok Barat & 49 \\
\hline 3 & Kab.Bima & 20 \\
\hline 4 & Kab.Dompu & 35 \\
\hline 5 & Kab Lombok Utara & 15 \\
\hline 6 & Kab.lombok Tengah & 15 \\
\hline 7 & Kota Mataram & 16 \\
\hline \multicolumn{2}{|c|}{ Total } & $\mathbf{1 7 5}$ \\
\hline
\end{tabular}


Dari hasil penelitian penulis menemukan fakta bahwa dengan adanya bantuan ini juga beberapa pelaku Usaha Mikro yang mendapat sentuhan anggaran stimulus Ekonmi merasa sangat diperuntungkan dilihat dari pernyataan wawancara diatas mengungkapkan bahwa betapa bermanfaatnya bantuan yang diberikan oleh Dinas Koperasi UKM Provinsi NTB sehinggga dapat meminimalisir kerugian selama Pandemi Covid-19 terhadap hasil penjualan pada pedagang kaki lima.

\section{Efektivitas Strategi Pemberdayaan UKM dimasa Pandemi Covid-19}

Efektivitas Strategi pemberdayaan UMKM dimasa Pandemi Covid-19 pada Dinas Koperasi UKM Provinsi NTB untuk mencapai suatu tujuan yang telah diterapkan oleh dinas Koperasi UKM Provinsi NTB mengenai strategi pemberdayaan yang sudah dijalankan, perlu dilalukan beberapa pengukuran-penguran yang berkaitan dengan bagaimana tujuan yang telah dicapai sehingga dapat mengetahu kesesuaian program yang telah dibuat berdasarkan lapangan.

Keefektvitasan Program ini dapat dilihat pada variabel menurut Budiani $(2007$; 53) yaitu :

\section{Sosialisasi Program}

Program Jaring Pengaman Sosial (JPS) gemilang dan Stimlus ekonomi oleh pemerintah pusat yaitu Pemeintah Nusa Tenggara Barat di tangani oleh Dinas Koperasi UKM Provinsi NTB. Budiani (2007: 53) menjelaskan bahwa peran penyelenggara program sangat penting salah satunya adalah sosialisasi penyelenggara program kepada masyarakat khususnya pelaksana program. Dengan cara ini, informasi tentang pelaksanaan rencana dapat dikomunikasikan dengan jelas. Informasi tentang program sangat penting dan harus dikomunikasikan kepada sasaran agar program dapat berjalan sesuai dengan tujuan yang diharapkan.

Jika teori Budiani's (2007: 53) dikaitkan dengan hasil dan penemuan, maka peneliti akan menemukan bahwa sosialisasi yang dilakukan adalah yang terbesar dan paling efektif. yang terlibat dalam kegitan adanya ratap melalui Daring, pelatihan dan pada beberapa nyuluhan melalui Kunjungan UMKM. Hal ini terbukti bahwa Usaha Mikro Kecil dan 
Menengah yang terlibat dari semua kabupaten/ kota di Nusa tenggara sendiri berjumlah 175 untuk program bantuan stimulus ekonomi dan Untuk Program Jaring Pengaman Sosial (JPS) Gemilang dalam pengadaan Alat Pelindung diri (APD) berjumlah 32 UMKM pada tahap I dan 85 UMKM pada tahap II. program ini sangat membantu untuk memberdayakan Usaha Miksro Kecil dan Menengah pada masa Pandemi Covid-19 yang diberikan oleh Dinas Koperasi UKM Provinsi NTB.

\section{Ketepatan Sasaran}

Akurasi tujuan yang direncanakan terkait dengan tingkat tujuan rencana yang telah ditentukan sebelumnya. Sektor usaha mikro, kecil dan menengah sangat penting ketika mengevaluasi efektivitas rencana karena untuk menentukan penerapan rencana yang dibuat oleh organisasi kepada kelompok sasaran. Jika menurut Budiani (2007: 53) teori tersebut berkaitan dengan observasi dan hasil penelitian peneliti di lapangan, maka ketepatan penargetan di bidang usaha mikro, kecil dan menengah terkait dengan JPS yang unggul dan memperoleh ekonomi. dana stimulus. Rencana tersebut secara khusus menyasar pada kelompok usaha yang benar-benar produktif sehingga dapat melakukan kegiatan ekonomi dan komersial bahkan pada saat pandemi Covid-19 juga dapat menyasar pada dinas-dinas usaha mikro penerima bantuan stimulus ekonomi yang terkena dampak standar bantuan koperasi UKM Provinsi NTB.

Dari hasil wawancara yang dilakukan oleh penulis tersebut bahwa program stimulus ekonomi yang diberikan kepada Usaha Mikro yang berkaitan didasarkan pada beberapa pertimbangan oleh Dinas Koperasi UKM Provinsi NTB. Pertimbangan tersebut berdasarkan kriteria yang telah dijelaskan, Hal ini dikarena bahwa sasaran Usaha mikro yang layak diberikan bantuan harus sesuai dengan kriteria-kriteria yang berkaitan dengan dampak Pandemi Covid-19 dimana usaha mikro yang dimaksud memiliki kriteria ; modal/ Aset suatu usha Mikro Berkurang, memiliki penurunan Omset serta likwiditas berkurang. Namun dari beberapa Usaha Mikro yang terdaftar mendapat bantuan tidak semua Usaha mikro yang mendapatkan bantuan anggaran Stimulus ekonomi tersebut dikarenakan keterbatsan anggaran daripusat hanya bisa mencakup 175 usaha mikro yang diserahkan dimasing-masing Kabupaten / Kota.

\section{Tujuan Program}

a. Memulihkan ekonomi UKM 
Terkait penanggulangan dampak ekonomi akibat Pandemi Covid-19 yang berdampak pada perputaran roda ekonomi khususnya pada sector Usaha Mikro Kecil dan Menengah, Dinas Koperasi UKM Provinsi NTB dalam program nya bertujuan untuk memulihkan Ekonomi masyarakat yang terdampak Pandemi Covid-19 pada UKM yang mengalami kesulitan dalam memasarkan barangnya karena kesulitan pembeli. meskipun demikian dengan pemulihan ekonomi ini para UMKM yang mendapat program JPS Gemilang dan Bantuan Stimulus ekonomi dari Pemerintah Provinsi NTB terlihat masih bisa bertahan.

b. Pengembangan Usaha

Penelitian di lapangan diketahui bahwa bantuan yang diberikan berupa Stimulus ekonomi oleh pemerintah tersebut tidak hanya digunakan sebagai modal saja bantuan yang diberikan juga digunakan sebagian untuk membuka usaha lain, seperti memfaatkannya untuk membuat sesuatu yang sekiranya dimasa pademi Covid-19 dapat diperlukan oleh masyakarat dan dapat dijual, hal ini dilakukan untuk menambah penghasilan mereka

Dari hasil wawancara peneliti dengan narasumber didapatkan sebuah fakta bahwa Tujuan dari Strategi pemberdayaan UKM dimasa Pandemi Covid -19 pada Dinas Koperasi UKM Provinsi NTB, dalam mengembangkan Usaha terlihat belum dapat mengembangkan para pelaku UKM dengan maksimal. disebabkan beberapa kendala dan keluhan yang dipaparkan oleh pelaku UKM itu sendiri dalam pengadaan masker. hal ini dikarenakan kendala daripemerintah pusat dalam permodalan sehingga dana yang terdapat di Dinas Koperasi UKM Provinsi NTB tidak mencukupi dalam memberdayakan Usaha Mikro Kecil yang bersangkutan.

\section{PENUTUP}

Berdasarkan hasil yang dibahas dalam penelitian ini, dapat disimpulkan bahwa efektivitas strategi pemberdayaan UMKM Dinas Kerjasama UKM Provinsi NTB pada saat pandemi Covid-19 belum dapat dikatakan baik diantara ketiga indikator yang dijelaskan. hanya dua indikator yang baik, yaitu indikator sasaran dan indikator sosialisasi terencana.

1. Strategi pemberdayaan UMKM dimasa Pandemi Covid-19 pada Dinas Koperasi UKM Provinsi NTB ini sudah tepat sasaran, hal ini dilihat dari sudah cukup banyaknya UKM yang menerima bantuan dan tersentuh disetiap kabupaten/kota di Nusa Tenggara Barat. 
2. Pemahaman program kepada masyarakat yang dilakukan oleh Dinas Koperasi UKM Provinsi NTB berhasil dengan baik, karena proses sosialisasi program pemberdayaan diketahui sejumlah UKM yang yang membutuhkan untuk memberikan pemahaman kepada masyarakat tersebut.

3. Tujuan program pemberdayaan ini tidak dapat dikatakan tercapai pada angka seratus persen karena disebabkan kekurangan dan kendala dalam pelaksanaannya.

Berdasarkan kesimpulan di atas, peneliti dapat memberikan saran untuk meningkatkan efektifitas strategi pemberdayaan UMKM pada saat pandemi Covid-19 yang diselenggarakan oleh Dinas Koperasi Usaha Kecil dan Menengah Provinsi NTB, yaitu:

1. Mengkoordinasikan dan mengadakan pertemuan lebih intensif dengan peserta UKM yang diberi kewenangan oleh ketua, kepala desa dan pendamping untuk lebih cepat menyelesaikan permasalahan terkait permodalan, sehingga tidak menjadi kendala dibelakang pelaku usaha.

2. Sebaiknya pemerintah menyediakan anggaran yang lebih dari yang telah diperuntukkan bagi penerima program pemberdayaan, karena bantuan yang diberikan berupa pemberdayaan pembelian alat Jaring Pengaman Diri (JPS) dan bantuan Stimulus ekonimi dalam pemberian modal yang menerima bantuan untuk memulai usaha dan merintis usahanya hingga tumbuh, berkembang, dan maju.

\section{DAFTAR PUSTAKA}

Republik Indonesia (2008). Undang-Undang Republik Indonesia nomer 20 tahun 2008, usaha mikro kecil dan menengah : Jakarta.

Raba Manggaukang (2020). Cara NTB dongkrak Ikm dan Umkm ditengah Pandemic Covid19 : Bandung

Dyah Ratih Sulistyastuti Dkk (2015). Usaha Kecil Menengah Dalam Pusaran Ekonomi Asean : Jakarta.

Fandy Tjiptono. 2006. Manajemen Jasa. Edisi Pertama. Yogyakarta : Andi.

A.Pearce, John II, Richard B.Robinson, Jr. (2014). Manajemen strategi. Salemba. Empat. Jakarta.

Bryson (2007:12.13). Perencanaan Strategi bagi bagi organisasi sosial : Yogyakarta, Pustaka pelajar. 
Garna, Judistira K.(2000). Metoda Penelitian : Pendekatan Kualitatif.: Primaco Akademika .Bandung

Totok dan Poerwoko (2013:14) Pemberdayaan masyarakat dalam perspektif kebijakan publik, Bandung.

Lestanata, Y., \& Zitri, I. (2020). Optimalisasi Sektor Pariwisata Pulau Kenawa Guna Meningkatan Pendapatan Asli Desa (PADes). Journal of Governance and Local Politics (JGLP), 2(1), 25-47.

Zitri, I., Rifaid, R., \& Lestanata, Y. (2020). Implementasi Dana Desa dalam Meningkatkan Kesejahteraan Masyarakat Desa Berdasarkan Undang-Undang Nomor 6 Tahun 2014 Tentang Desa. Journal of Governance and Local Politics (JGLP), 2(2), 164-190.

Pakei, Beni. (2016). Konsep dan Analisis (Efektivitas Pengelolaan. Keuangan Daerah di Era Otonomi Daerah). Jayapura: Taushia.

T. Ediraras Dharma (2018) “Akuntansi dan Kinerja UKM,” Jurnal Ekonomi Bisnis. 15, no. 2 (2010): 153, diakses tanggal 18 Desember. https://ejournal.gunadarma.ac.id/pdf

Berry Tambunan (2009) "UMKM di Indonesia 1" .http://repository.iainkudus.ac.id/3008/10/5.\%20BAB\%20II.pdf.

Nazir (1988: 63). Contoh Metode Penelitian, : Bandung.

Ratcliffe, Rebecca (2020). "First coronavirus cases confirmed in Indonesia amid fears nation is ill-prepared for an outbreak". The Guardian (dalam bahasa Inggris). Diakses tanggal 2 Maret 2020. https://id.wikipedia.org/wiki/Pandemi_COVID-19_di_Indonesia

Worldometer (2014:29), Coronavirus Update (Live): 307,627 Cases and 13,050 Deaths from COVID-19 Virus Outbreak .

Heryana Ade, S.ST, M.KM. (2015: 4). "Informan dan Pemilihan Informan Pada Penelitian Kualitatif".

https://www.kompas.com/global/read/2020/10/07/184101970/masuk-10-bulan-penyebarancovid-19-begini-kondisi-seluruh-negara-di-dunia?page=all.

Allard, Tom; Lamb, Kate (28 April 2020). "Exclusive: More Than 2,200 Indonesians Have Died With Coronavirus Symptoms, Data Shows" https://id.wikipedia.org/wiki/Pandemi_COVID19_di_Indonesia. 
Steers M Ree(1985: 209L http://library.binus.ac.id/eColls/ehesisdoc/Bab2/2013-1-00190MN\%20Bab2001 Olsen ,Eadie (dalam Bryson, 2007:5).

http://library.binus.ac.id/eColls/eThesisdoc/Bab2/2013-1-00190-MN\%20Bab2001.

Sudjana Nana, (Sinar Baru 1998:84). "Penelitian dan Penilaian”: Bandung.

Fatoni Abdurrahma , (Rineka Cipta,2011:104). "Metodologi Penelitian dan Teknik Penyususna Skripsi ”. Jakarta.

Masri Singarimbun, Efendi Sofran ( 1995:46.8). Metode Penelitian Survey : Jakarta.

Sugiyono, (CV Alfabeta,1998.300). Metodologi Penelitian Administrasi : Bandung.

Muhammad farid Said, (2015) "Strategi Pemberdayaan UMKM pada Dinas KOPERINDAG kabupaten Maros (Studi Kasus pada Sektor Perdagangan). http://library.binus.ac.id/eColls/eThesisdoc/Bab2/2013-1-00190-MN\%20Bab2001. 